\title{
THE GOVERNANCE OF SOCIAL SCIENCE AND EVERYDAY EPISTEMOLOGY
}

\author{
CLAIRE DONOVAN
}

Research on the governance of publicly funded research does not recognize that social science and 'science' are distinct activities. Neither does it recognize that regulating research policy in purely science and technology terms has undesirable consequences for the social sciences - intended or otherwise. This paper seeks to correct these omissions and considers the governance of social science through the example of regulating 'everyday epistemology' at the science policy level. The British research council system is used in order to demonstrate how social science has been politically constructed as a legitimate enterprise for public funding. We find that social science is in fact regulated by non-social scientists. The result is that social science, seen as a square peg, is forced into the round hole of natural scientific thinking. When this policy is translated into governance structures it creates a 'slave social science' and subverts the role of social science as social science.

\section{INTRODUCTION}

Historically, the governance of science includes the governance of social science. The purpose of this paper is to ask at what cost to the future of social science? As this paper will outline, the price is nothing less than creating a 'slave social science' and undermining the role of social science as social science.

The aim of this paper is to make the case that while there is research into the governance of science, there is a need for separate research into the governance of social science. The literature on the governance of science does not recognize that science and social science are distinct activities; nor does it consider that regulating social science as if it were 'positivistic' science produces undesirable consequences.

This paper addresses the governance of social science using the example of regulating 'everyday epistemology' at the science policy level. The term 'everyday epistemology' is used to signify that theories of knowledge are not confined to a transcendental philosophical realm, but are grounded in routine scientific and social scientific practice. Epistemology is also 'everyday' in a political sense since it can be used rhetorically to compare or differentiate scientific and social scientific spheres. British science policy documents allow us to trace how, in the second half of the twentieth century, the role of social science has been politically constructed as a legitimate enterprise for 
public funding. We find that the 'everyday epistemology' of social science is regulated by non-social scientists and this square peg is thus squeezed to fit the round hole of natural scientific thinking. This produces a social science that makes sense to natural scientists.

Remaining with the case of the British research council system, and drawing upon previous empirical research (Donovan 2002, 2003), we find that when this regulation of everyday epistemology is translated into governance structures it creates a 'slave social science' and also denies the role of social science as social science by perpetuating what has been called the 'science wars'. First, social science is epistemologically 'enslaved' by a science and technology policy that defines social science's purpose as belonging to and working for science. Institutional arrangements then follow that restrict social science's freedom, making it 'slavish' within a research council policy network where financial incentives steer the ESRC towards offering complete obedience to an overarching science and technology orientation. It also means accepting a subordinate function in formulating research directions when, for example, we find that national thematic priorities are created by a research council policy network where social science lies at the margins. The contribution of social science, then, is not predicated on its own terms. Regulating social science as science also perpetuates the 'science wars' by privileging 'positivist' social science and thereby overlooking the potential utility of interpretative and reflexive social science and their associated anthropological methods. In both instances we find that what is considered to be legitimate social science is being regulated through the policy network by non-social scientists. These examples are practical manifestations of the institutional governance of social science and demonstrate that regulating social science as science does not work.

To successfully regulate social science as social science the mode of governance needs to change. As this paper makes clear, science and technology policy can redefine social science as empirical social science plus 'added interpretative value', and thus fully utilize its full spectrum of approaches and methods, and thus allow social science to contribute to the research council policy network on its own terms. The paper concludes by outlining future research directions, including reflexively applying the notion of regulating everyday epistemology back to science and technology themselves, asking if they too may be similarly in thrall.

\section{THE GOVERNANCE OF SCIENCE}

There are two main sources of literature which deal with the governance of science. Somewhat surprisingly, work that explicitly addresses the governance of science has the least to say about the governance of science - at least in the sense that this kind of governance is generally understood within the political science literature. For example, in The Governance of Science (2000), Fuller does not categorically set down what he means by the term 'governance', although his position is enigmatically summarized by his epithet: 
'That science both governs and is governed without being formally considered as a government' $(2000$, p. 8$)$. On the one hand he details the Leviathan-like qualities of science as an institution: 'Science is a vehicle of global governance', and 'the mystery surrounding science as a political concept lies less in its day-to-day business (i.e. "research") than its capacity to speak on behalf of the whole of humanity in a way that transcends national differences as well as other cultural and economic barriers'. On the other hand, Fuller is interested in the internal politics of science, which is generally perceived to be a democratic institution although it is governed by a self-selected scientific elite. Fuller is ultimately preoccupied with the dual interests of democratizing science as a powerful unelected institution that governs, and democratizing science in terms of who can participate in it and how. He is not concerned with how scientific research is regulated or shaped by government policy.

The second, and most fruitful, source of literature on the governance of science, deals with the governance of national research policies. This implicitly addresses the governance of science because the policies studied are without exception premised upon the government or governance of science and technology research. It is this literature which is reviewed below, and in this context 'research policy' is taken to be the equivalent of 'science and technology policy'.

However, nowhere does the 'governance of science' or 'governance of research policy' literature consider the peculiar place of social science (or indeed the arts or humanities) within science governance. The most striking example of this is an in-depth OECD report on UK research governance (2003b), which specifically studies the research councils, and only mentions the Economic and Social Research Council (ESRC) in a list of research council names - all examples and illustrations in the report are purely science and technology based. Even where science is defined as Wissenschaft, to include all academic disciplines (Fuller 2000, pp. 7-8; MUSCIPOLI (Managing with Uncertainty in Science Policy) 2003, para 1.5), social science is not separately analysed, and the effects of focusing on the governance of science in terms of the experimental science paradigm alone are neither recognized nor considered.

\section{Why science governance?}

Why do nations have a science research policy? And why is it important to think about this in governance terms? The collective narrative resonates with the terms 'utility', 'commercialization' and 'wealth creation'. Governments believe that scientific discovery creates social and economic progress, and so they desire to harness scientific research towards the twin causes of national technological advance and enhanced international competitiveness. In the pursuit of these goals, governments wish to derive maximum utility out of finite public funds while directing the research effort as efficiently as possible. This is the genesis of science governance. 
Féron and Crowley (2003, p. 381) point to a growing 'consciousness' among European policy-makers that 'policy levers' or incentives are the means to achieving the ends of research quality and economic competitiveness. This entails the introduction of competitive research funding or regular evaluation procedures, which follow the mantra that only 'useful' research deserves funding. The same trend is recognized in the wider international context of OECD countries: that there are growing government demands for science systems to change in order to compete, and a catalyst for this is recognized in the governance of public research funding, decision making and priority setting, as well as the assessment of institutions in relation to their contribution to knowledge creation, economic growth and social needs (OECD 2003a). We are witnessing an internationalization of science policy in its rhetoric and in its increasingly uniform national manifestations. This hails the idea of cross-national competitiveness leading to a homogenized research orientation - a global governance premised upon the progressive promise of science and technology research. But what does this utopian (or dystopian) technocratic vision entail for the future of social scientific research thus conceived?

It is politically interesting to note that the largely eurocentric focus of the governance of research policy literature is directly linked to European Union funding (Caswill 2001, 2004; Hackmann 2001; Féron and Crowley 2003; Guena et al. 2003; MUSCIPOLI 2003). This is reflexive in two respects: (1) that this research on research governance is itself the product of research governance in the form of EU research initiatives; and that (2) some of this 'useful' research is being utilized by science research funders to greater understand and hence attempt to control research governance processes (MUSCIPOLI 2003, n.d.). This is part of a trend that was recognized as early as 2000 when Funtowicz et al. (2000) observed increasing attention at the European level to scientific aspects of research policy and administrative decisions, and noted that the European Commission was adopting guidelines in areas such as the management of knowledge. A high profile example of EU-funded research on research governance is the Managing with Uncertainty in Science Policy (MUSCIPOLI) Project, financed by the European Fifth Framework Programme. This project is largely comprised of research administrators, and seeks to identify important trends in the governance of science. It asks: 'in terms of achieving science policy goals and/or priorities... how does the mode of governance affect the governability of science in various national and/or international settings?' (MUSCIPOLI n.d., p. 2). The project also provides guidelines for research funding organizations, for example, 'managing policy (including directive and responsive research), managing relationships (including budget ministries, academics), getting the science right, and managing research outputs and outcomes (including evaluation)'. We may question whether this research is seeking merely to better understand the processes of science governance, or if it is an attempt to utilize this knowledge with the aim of increasing science government. 


\section{What is science governance?}

To understand what science governance is and how it operates, it is necessary to distinguish between the government and governance of research policy. Research government is recognized as the implementation of research priorities by a research policy elite in a top-down, codified manner which does not embrace ideas coming upwards from the academic constituency. Research government denotes: 'conventional policy concern with the production and formulation of rules forbidding or compelling actions or classes of actions; the monitoring of compliance; and the implementation of sanctions' (Féron and Crowley 2003, p. 373).

However, the general consensus in the literature is that attempts to govern research have been abandoned since: "It is not possible to "order" research' (ibid. 2003, p. 385). One reason for this is that research policymaking is 'information-deficient' - only those who can do the research have the knowledge of what can be done. In this light only general goals and means can be planned for since researchers cannot produce results in advance. It follows that: 'Active compliance cannot be mandated' by research policy, and that there should be cooperation between policymakers and researchers rather than 'simply passive compliance' (ibid. 2003, p. 385).

For example, in their Europe-wide study, Féron and Crowley provide an overview of policy initiatives between 1987 and 2000 that points to a common trajectory of change from research government to research governance: "in the direction of "steering" policies using negotiation and, above all, incentive structures, rather than major institutional transformation, aggregate planning, top-down priority setting [and] strategic resource allocation' (ibid. 2003, p. 381). The general picture is that governments are perceived to realize that research cannot be managed hierarchically, believing that government of research 'is neither possible nor desirable' (ibid. 2003, p. 385), and they either drift towards or actively embrace policies that favour research governance, realizing that while research cannot be directed it can be steered if consensus is gained. Indeed, the governance of science and technology research is taken as 'the paradigm case' for applying governance theories to policy: 'Here, policy, it seems, can do little more than define very general objectives and provide a framework for research activity' (ibid. 2003, p. 373).

It may, however, be naïve to believe that research government has simply melted away to be replaced by research governance. For example, an interesting question to consider is whether national thematic priorities and foresight exercises are best understood in the context of research government or research governance. For Van der Meulen (1998), an erosion of state trust in the self-organizing processes of science and an increase in evaluations, national research initiatives and foresight exercises, points to research government. Hackmann finds mixed modes of governance in operation when, for example, she views UK Foresight exercises as network-based 
(governance) and the accompanying centralized research priorities as hierarchical (government) (Hackmann 2001, pp. 26-7). In contrast, Féron and Crowley $(2003$, p. 386) find that while the idea of large research initiatives seems to imply a model of government: 'It is only a superficial paradox that their changes correlate with a move away from a planning or command approach to policy'. In other words, while research initiatives may seem to be directive, they in fact accommodate more governance and less government. However, they also take the view that while research governance may in theory appear to be less interventionist than research government, it may at times be more 'hands on' than government (ibid. 2003, p. 373).

Despite such conflicting examples, little doubt is expressed within the literature that governance rather than government is the dominant mode by which science and technology policies are implemented. But how does governance operate? The answer is through 'steering' - that is, indirect government influence. In other words, decentralized steering is a form of scientific self-regulation, although the government still decides the policy (Hackmann 2001, p. 21). 'Steering' is an ambiguous term, and a popular explanatory account of this within the science governance literature is borrowed from new public management discourse, applying the principal-agent model to the policy sciences in order to picture how policy is translated from the government to dedicated agencies. In a nutshell, principal-agent analysis states that a principal (government) transfers resources to an agent (a scientist) to realize objectives which the principal cannot achieve (to conduct scientific research). In addition, the transfer of resources gives the principal the right to monitor the agent (Van der Meulen 1998, pp. 399-400). Principal-agent studies focus on what incentive structures would attract agents (scientists) to the interests and objectives of the principal, and what strategies agents adopt to make their own objectives dominant. Braun (1993) notes that an agent can also be a research agency, so scientists can become a third party in this relationship.

The key, then, to understanding how governance structures operate is the use of incentives (also referred to as 'levers'), which are the 'resources available at the level of the state that can be mobilized in the pursuit of specified objectives with at least partially predictable outcomes' (Féron and Crowley 2003 , p. 379). In this manner the autonomy of the research sector can be utilized by the state as a policy resource to steer scientists towards planned policy objectives. Major levers include funding and career patterns. Funding is an important lever simply because research often depends upon the funds made available by the state, and effective governance can exploit this by ensuring that basic funding is available at lower levels than initiatives, steering researchers towards pursuing research in pre-defined national priority areas. Employment policies can make career patterns become levers in systems where, for example, fixed-term contracts are favoured over tenure and their renewal is part of a competitive process, steering researchers to apply for public funding (ibid. 2003, p. 383). 
We have seen that research funding has become more governance-driven in recent years, and this has wide-reaching implications for social science research that is set within a 'one size fits all' science and technology policy. We shall see that regulating social science under these auspices produces undesirable outcomes that backfire against policy intentions - for example, the distinctive features of social science are unaccounted for, undermining its potential 'utility'. In this respect, what is fast becoming the global mode of science governance is inadequate and needs to change.

\section{THE GOVERNANCE OF SOCIAL SCIENCE}

In contrast to the governance of science, there have to date been very few attempts to apply governance theories directly to the social sciences. The small amount of research that exists has a largely Canadian and British orientation, and is confined to the study of the regulatory powers of research ethics committees. While it has limited general application, this work relates to several themes drawn out in this paper, such as: (1) the external desire to regulate social scientific activities; (2) the bureaucratization of social science research; (3) imposing inappropriate scientific models upon the social sciences; and (4) the democratization of research.

This interest in governance was originally prompted by medical researchers becoming aware that psychologists and sociologists engaged in similar activities to their own were often exempt from submitting research proposals to ethics committees (for example, British social scientists conducting medical research funded outside the National Health Service). Claiming concern primarily for the protection of research subjects, Williamson et al. (2002) expressed the worry that social science research slips through the ethical review net. While self-regulation exists in various forms (professional guidelines, peer review, funding application procedures, and steering and advisory groups), this is viewed as inadequate since it does not meet the increasing demands 'in the current political and economic climate' for accountability and democratic science (ibid. 2002, para 6.2). Regulation of social science research is called for in the form of ethics review committees modelled upon existing scientific practice. 'Whilst "academic freedom" and fears of censorship are important these concerns relate, [sic] to the wider debate about whose interests do social researchers serve and what is the role of government (trans-national) regulatory bodies in ensuring that standards of ethical practice and good quality science are maintained?'

Ethical review of social science is not necessarily limited to medical research and is commonplace in, for example, Australia and the USA. Some critics of review committees fear an incipient policing of social science research by 'bureaucratic gatekeepers who use ethics as managerial ideology' (Furedi 2002, p. 20). This regulation is seen to be driven by applying a model of risks and benefits to research subjects that is based on biomedical ethical principles that are inappropriate for general social science. There is also concern about a lack of transparency or the 'research ethical review 
black box' since ethics committee proceedings are conducted in secret (Fitzgerald and Yule 2003), and this in fact makes for undemocratic science.

This cluster of research on the governance of social science remains an isolated phenomenon. We have seen that the governance of social science has not been addressed by the literature on the governance of science. Here social science is either treated as part of a homogenized, technocratic science (OECD 2003a) or is recognized in the sense of being part of Wissenschaft (MUSCIPOLI 2003, para 1.5) but not analysed differently. Nowhere has it been considered that social science and science are different enterprises, or that science governance has undesirable consequences for the social sciences, intended or otherwise.

Such an omission is a curious one. It is not entirely surprising that the distinctive features of social science are overlooked by policy-makers or scientists, but it is quite remarkable that social scientists engaged in researching science governance do not recognize this. While reflexivity is discussed (see, for example, Féron and Crowley 2003, p. 372), no social scientist has thought to apply this notion to their own endeavours and ask how the governance of science impacts upon their own research activities or how it affects social science generally. And nowhere does the governance of science literature discuss everyday epistemology, or what is considered legitimate social science research, or what an unfettered publicly funded social science would be like in its approach and its contribution to national research directions.

\section{The governance of social science and everyday epistemology}

That there is undoubtedly a strong case for studying the governance of social science is clearly illustrated using the idea of regulating everyday epistemology at the science policy level. While this may seem to be a rather abstract example of the governance of social science, everyday epistemology in fact is an ideal starting point since it cuts straight to the heart of the fundamental differences between science and social science; it also helps reveal the various undesirable outcomes of regulating social science as science.

As has been said, the term 'everyday epistemology' is used to signify that theories of knowledge are not confined to some transcendental philosophical realm, but underpin routine scientific and social scientific practice. Epistemology is also 'everyday' in a political sense, and can be used rhetorically to compare or differentiate scientific and social scientific spheres. But what has this to do with governance? Are we to believe that policy-makers take the time to philosophize about the scientific status of social science? Taking the British case as an example, this is precisely what has happened on several occasions, and policy documents (Clapham 1946; Heyworth 1965; Rothschild 1982; Office of Science and Technology 1993) allow us to trace how the role of social science research has been politically constructed as a legitimate enterprise for public funding. King (1998) does not mention governance, but studies the Clapham and Heyworth reports to relate how 
consensus politics in Britain created the political need to stress the neutrality of publicly funded social science research and consequently produced a bias towards 'positivistic' scientific methodologies which were seen as untainted by ideology. Donovan $(2003$, p. 3) maintains that these government documents 'provide an insight into policymakers' changing attitudes towards the scientific status of social science during the second half of the twentieth century and illustrate the various rhetorical manoeuvres employed in order to squeeze this square peg into the round hole of natural scientific thinking'.

The 1946 Clapham Report considered whether there should be a research council for the social sciences, and decided against this. The report was produced at a time of academic and establishment hostility towards the social sciences, which were thought to lack the strict methodological rigour of the natural sciences while not possessing the intellectual respectability of the humanities (which did not dare to harbour scientific pretensions) (King 1997). Yet this early policy document reveals a sophisticated understanding of social science's interpretative and reflexive credentials that is rarely observed in later years. For example, the natural and social sciences are compared and found to diverge in their remit, methods and relationship to their subject matter.

There are profound differences between the natural and the social sciences, depending partly upon the nature of the subject matter, partly upon the technical methods which are apparent in each sphere. The leading method of many of the natural sciences is controlled experiment; in the nature of things, the social sciences present much less scope for this method. The subject matter of the natural sciences is independent of the results of research; research in the social sciences may itself change the subject matter it has to deal with. (Clapham 1946, p. 5)

However, the report recommendations came out against forming a research council for social science on very different epistemological grounds, brushing aside any notion of fundamental difference by arguing that social science research did not yet warrant public funding and needed time to mature until it could replicate the methods of natural science, match its achievements and thereby similarly contribute to national wealth creation. A glimpse of the imagined future utility of social science is offered using the example of economics, which is taken to exemplify the empirical refinement and policy application to which social science may aspire. Sociology, on the other hand, is seen to represent all that is lacking in the current state of the social sciences: interpretativism is viewed as a weakness, and there is genuine concern that sociology's left-leaning orientation would mean that the premature public funding of the social sciences could foster 'a crystallisation of spurious orthodoxies' (Clapham 1946, p. 29).

Two decades later, the Heyworth Report recommended the creation of the Social Science Research Council (SSRC) (Heyworth 1965). The report does not discuss the epistemological status of social science, although implicit 
assumptions are apparent. For example, Heyworth offers a technocratic model of a fact-finding, multidisciplinary social science bound to 'user' requirements (ibid. 1965, p. 17). Social science is firmly recast in an idealized natural scientific mould, as a problem-solving activity that can 'fix' things or offer permanent solutions. But this technological conception of social science did not convince all of its critics, and while its interpretative and ideological aspects were glossed over at the science policy level they nonetheless remained - and were clearly at odds with a positivistic ideal of science. This inherent epistemological disjunction almost proved disastrous for the social sciences in Britain. A further two decades later, tackling these perceived weaknesses became a personal crusade for Keith Joseph, the Conservative Secretary of State for Education and Science, a self-proclaimed disciple of the Popperian model of science who opposed the very idea of a social science. For example, I have elsewhere related how, in government documents and personal communications, Joseph could not bring himself to use the term social 'science', preferring social 'studies' (see Donovan 2002, p. 231).

Joseph waged war against the SSRC and, backed by senior Cabinet colleagues, launched a government enquiry intended to liquidate or dismember this public body. It was everyday epistemology that motivated Joseph's antagonism, and this is directly addressed in the 1982 Rothschild Report into the SSRC (Rothschild 1982). Rothschild eloquently elaborates upon the foundations of the social sciences in the work of Condorcet, Mill and Durkheim, and states that while 'the true lack of analogy between the physical and social sciences was only slowly recognised' (ibid. 1982, para 4.1), social science is intrinsically valuable (ibid.1982, para 4.2). Rothschild crushingly describes a Popperian view of science as entirely inapplicable to understanding social science (ibid. 1982, paras 4.4-4.12) although he concedes that the 'excessive claims of sociology' (under fire here again) had caused an understandable backlash against the social sciences. While this report acknowledges fundamental differences between the social and physical sciences, the preference for a science-driven mode of social scientific enquiry remains. While the SSRC survived this onslaught, the cost included an epistemological victory for Joseph who forced the Council to change its name. On the suitably Orwellian date of 1 January 1984, the Social Science Research Council was renamed the Economic and Social Research Council (ESRC). While the word 'Science' may have disappeared from the ESRC's title, it continued to define, from without and within, the ESRC's terms of engagement as part of the science research funding system.

The Clapham and Heyworth Reports are examples of government attempts to regulate the everyday epistemology of social science; the Rothschild Report was commissioned as part of the desire to directly govern the political orientation and scientific status of social science research. We have previously noted the view that efforts to govern science research in a topdown manner have been unfruitful (Féron and Crowley 2003, p. 385). In this 
respect, the 1993 White Paper Realising Our Potential (Office of Science and Technology 1993) is progressive in that it directly embraces a model of science governance. This legislation transferred the research council system from the Education Department to the newly created Office of Science and Technology, and the research councils were restructured into what we would recognize as a policy network designed to produce a nationally coordinated science and technology research effort, dependent upon close inter-council cooperation and steered towards the express utilitarian goal of national wealth creation. This policy document does not venture into the realms of epistemology, nor does it refer directly to social science or distinguish it from any other kind of scientific activity. Policy debates about the scientific status of social science had by this time become historical artefacts. The 1993 White Paper subsumed social science within a natural science model, taking epistemological equivalency for granted. We shall see below that while Realising Our Potential did not concern itself directly with everyday epistemology, it has produced the most effective means for the governance of social science as science.

The cumulative effect of British science and technology policy upon regulating the everyday epistemology of social science has been to produce a variety of undesirable outcomes, intended or otherwise, because there is a mismatch between what social science is and how it has been politically defined (as regular science) by government actors who are non-social scientists. We shall see below that the actual implementation of these policies has led to the creation of a subservient social science and has subverted the role of social science as social science.

\section{Creating a 'slave social science'}

This paper uses insights gained from theories of governance to reinterpret previous empirical studies of research direction (Donovan 2002, 2003) and the examples that follow are derived from these sources. The notion of a 'slave social science' evolved through studying the interactions involved in creating UK research council thematic priorities and observing how crosscouncil negotiations act to marginalize the potential role of social science. Using data from elite interviews, policy documents and other official publications, this research found that 'under the present UK national research strategy the place of social science is at its margins as an adjunct to the "real science"' and 'the public funding of social science research within a national science and technology framework creates "social science in the service of science and technology"' (Donovan 2003, pp. 1-2). The paper expands upon this work to demonstrate how a 'slave social science' is ultimately the product of regulating everyday epistemology. For example, we have seen that social science is epistemologically 'enslaved' by a science and technology policy that defines social science's purpose as belonging to and working for science. We shall see that institutional arrangements follow which then restrict social science's freedom, making it 'slavish' within a research council 
policy network where the ESRC is steered by financial incentives to offer its obedience to the overarching science and technology orientation and to accept this subordinate function. We find that national thematic priorities are created by a research council policy network that a subaltern social science cannot contribute to on its own terms.

The push to create national thematic research priorities came from Realising Our Potential (Office of Science and Technology 1993). Pre-1975 there was no directed social science research, and then, in the cause of justifying public expenditure, the Advisory Board for the Research Councils (ABRC), which oversaw research council budgets, applied pressure on research councils to create research initiatives - at first in isolation and then in conjunction with each other. In this climate, the SSRC created a Research Initiatives Board as a visible mechanism for driving research towards applied and 'relevant' research initiatives. The intent was to appease the ABRC, but this move had far more substance than mere 'impression management' because, in science and technology policy terms, producing this kind of research was the SSRC's raison d'être. However, this inevitably meant proving social science's scientific credentials to non-social scientists in terms of subject matter and research methods, albeit through a combination of some window-dressing and some reality (Donovan 2002, pp. 111-50).

This arrangement became formalized post-1993 when the research council system was restructured to form what we would call a policy network. Foresight exercises brought together various 'stakeholders' from government, science and industry to 'shape research policy around one of the characteristic projects of high modernity: maximising the competitive efficiency of the national economy' (Moran 2003, p. 144). Foresight exercises guide crosscouncil collaboration in generating suitable thematic priorities through a series of ongoing Spending Reviews, to be approved by the Director General of the Research Councils, the Minister concerned, and then the Treasury. We can identify the research councils as a policy network if we view the state as contracting out science research for the research councils to manage. This research council network is virtually autonomous of government, although steered by various 'levers' or financial incentives to conform to Foresight preferences to the satisfaction of the Director General and, ultimately, the Treasury.

In general governance theory, trust forms the 'basis of network co-ordination' and 'shared values and norms are the glue which holds the complex set of relationships together' (Rhodes 2003, p. 66). In turn, a successful Spending Review round depends upon close inter-council cooperation in producing coordinated collaborative science and technology projects, a relationship which has been cemented by forming the umbrella organization Research Councils UK (RCUK), an organization devoted almost exclusively to this task. It is only under these post-1993 arrangements that a highly harmonized science and technology policy has been pursued, and we encounter research governance directed towards generally prescribed government 
goals. This has fundamentally changed the role of social science in the research council system because the ESRC can only successfully participate in the policy network, and increase its resources, by mirroring the fixed aims of the overarching science and technology orientation - as witnessed by the accounts of various ESRC Chief Executives (see Donovan 2002, 2003, pp. 6-7). Social science can be said to be governed or 'enslaved', then, because the policy network is driven (at the Foresight and research council level) by non-social scientists who collectively fail to distinguish social science from general science. It is thus 'slavish', or coerced, because the process of cooperative governance entails that the ESRC has to share inappropriate values and norms which act against pursuing social science-led initiatives, and social science finds itself misplaced and lacking freedom or autonomy within the policy network. It is within this context that the ESRC began to produce its own internal thematic priorities to complement Foresight planning, driven by the desire to maximize ESRC funding, and the wish to transform itself from a 'buffer' between social scientists and government to a research 'broker'. At the same time the ESRC strategically adopted language games to fit the discourse of science policy, and within the policy network it continued to promote social science that matched the 'positivist' paradigm. Yet if we scratch the surface we find that these ESRC initiatives are deliberately responsive, pointing to a potential rift between policy network interests and social science practice. However, the focus of this paper is on top-tier activities rather than the drivers and outcomes of internal ESRC policies and these are elaborated at length elsewhere (Donovan 2002, pp. 260-303).

Thus a 'slave social science' is born, and this is clearly illustrated by the thematic priorities that emerge from the policy network. For example, the 2004 RCUK thematic priorities were: e-Science, Basic Technology, Genomics, New and Emerging Science and Technology, Towards a Sustainable Energy Economy, a Long Term Technology Review, and Rural Economy and Land Use (Research Councils UK 2004). The latter has more obvious social science application and the ESRC took a leading role in designing this initiative, but in all other cases the place of social science at this policy level is limited to a tacked-on 'the social consequences of...' or 'social aspects of...'. The outcome of policy network deliberations is that 'governments support social science that makes sense to natural scientists' which is 'social science in the service of natural science and technology' (Donovan 2002, p. 18). Epistemological parallelism has become firmly embedded in the policy network through using financial incentives to steer future research directions. Successful bids must conform to and thereby reinforce government policy expectations and assumptions.

The 'slave social science' thesis is particularly important when we consider that 41 per cent of ESRC research funding in the financial year 2003-04 was tied to research priorities, which were in turn tied to thematic priorities (Economic and Social Research Council 2004, p. 105). We have previously 
noted here that across Europe science governance has been found to be on the increase and to be correlated with the pursuit of science and technology driven national research goals (Féron and Crowley 2003, p. 380), a pattern that is duplicated in wider OECD countries (OECD 2003a). While this international trend increases unchecked, social science as social science has a diminishing - if not disappearing - status at the national research policy formulation level.

'Slave social science' serves as a simple example of the pervasiveness of everyday epistemology when translated from policy documents to research governance structures. At the science policy level, what is considered to be legitimate social science is an externally imposed natural scientific conception of social science, an erroneous vision reinforced in the UK case by the research council policy network where social scientists will always form a minority and a small minority at that.

\section{Perpetuating the 'science wars'}

The impact of regulating everyday epistemology at the policy level extends beyond dictating research directions. External (often combined with internal) constructions of the usefulness of 'positivistic' or empirical social science affect the perceived legitimacy of alternative social science approaches. This conception of social science acts to prolong the 'science wars' and overlooks the potential utility of interpretative social science and its associated methods.

The term 'science wars' is taken from Flyvbjerg (2001, pp. 1-3) and depicts the perennial battle over the foundations of social knowledge. Is social science a strictly scientific, objective fact-finding activity based upon empirical investigation? Or are 'facts' merely constructions, and the best we can achieve is a subjective understanding of the meanings and interpretations of social actors garnered through using anthropological approaches? Put more crudely, is social science 'positivist' or interpretative? The governance of everyday epistemology privileges the former and disregards the latter.

It is proper to admit that underlying this paper is the assumption that there is a 'natural' form of social science that embraces pluralism, and assumes that quantification and interpretivism are not mutually incompatible. This paper demonstrates that this view is not accepted at the science policy level, and it is hotly contested between social scientists. Hermeneutic circularity suggests that proponents of these alternative visions of social science will remain divided, one side maintaining that interpretivism is deviant social science. However, the question this paper seeks to answer is not what social science is, but why a system of governance has come to favour particular approaches over others.

It is interesting to note that sociology is the social science discipline that has been singled out by policy documents for its lack of objectivity or deficiencies of method. Indeed, it has become traditional sport for government reports to disparage sociology in some form while praising the discipline of 
economics (Donovan 2003, p. 4). This situation has some roots in right-wing hostility towards sociologists, but beyond juxtaposing a rather naïve impression of sociology with an idealized picture of economics, this misconstruction is emblematic of the poles of the science wars and the perceived strengths and weaknesses of social science generally. Reflexivity, interpretativism and social theory stand in sharp relief to highly quantitative, applied 'positivistic' research.

The 'science wars' rage within social science, recent British manifestations include symposia that address this issue - directly in sociology (Goldthorpe et al. 2004) and indirectly and, somewhat ironically in the context of this paper, in a political science discussion of what may be termed the social science of governance (Finlayson et al. 2004). These internecine spats are what help to define the boundaries of social science and its everyday epistemology from the inside, and demonstrate that 'positivist' approaches are strongly supported from within and are not simply imposed from above. However, the point here is not what social scientists do or do not believe to be genuine social science, but the fact that at the policy level this decision has been taken out of their hands and is being externally regulated by nonsocial scientists. The policy preference is to model social science upon idealized natural scientific practice, favouring user-oriented, fact-finding, 'positivistic' approaches and their associated (and preferably quantitative) empirical methods. It follows that within the research council policy network there is no room for the ambiguity of interpretative social science (which is highly unlikely to be funded in Foresight terms). The ESRC stands to gain more trust, and secure greater resources, by promoting social science approaches that can be understood by the network, and have demonstrable relevance for achieving the network's goals.

Regulating the everyday epistemology of social science as science perpetuates the false dichotomy that is the 'science wars'. 'Useful' social science becomes defined as 'positivist' social science, in contrast to the 'fuzzy thinking' of interpretative or reflexive social science and social theory. While the governance of everyday epistemology embraces a 'positivist' model of scientific practice, we must beware of confusing positivism with empiricism, since even highly quantitative empirical research is not necessarily premised upon the epistemological equivalency of the natural and social sciences. However, many social scientists will embrace the policy-makers' vision because social science can be all the things required of it within the national science and technology framework. It can, however, also be more - hence the current controversies. Social science comes in more than one form 'positivistic' research is not the sum total of social science, and interpretative sociology and its associated anthropological methods can be both 'useful' and have 'application'.

This can be demonstrated here in an interpretative manner. Following competing definitions of governance as 'government without government' and 'government with more than government' (Kjaer 2004, p. 28), it can be 
similarly argued that the value of interpretative social science can be described both as: (1) social science without science; and (2) social science with more than science. In other words, in addition to, for example, applied quantitative social science, further explanation and understanding can be afforded by also using interpretative and reflexive approaches and methods that are not universally recognized as social 'science' but add more to our understanding of issues than quantitative social science in isolation. In this sense interpretative social science does have utility, something that could be understood in policy language as 'added value'.

In governance terms, interpretative social science has become the social science that dare not speak its name. However, while the system of governance may favour certain 'outputs' it does not produce these alone: interpretative social science, although not recognized at the policy level or promoted within the research council policy network, nevertheless exists. This disjunction between policy and practice is evidence that social science is being subject to inappropriate regulation. It would be simple to end the 'science wars', at the policy level at least - and to remove the contradiction between funding social science as science and actual social scientific practice - by embracing 'useful' (and hence legitimate) social science as empirical social science plus added interpretative value. So long as the governance of social science privileges 'positivism' and its associated methods, the terms of engagement of the 'science wars' will remain, and the distinctive features of social science will continue to be ignored.

\section{CONCLUSION}

The governance of science includes the governance of social science, and the aim of this paper has been to make the case that while there is research into the governance of science, there is a need for separate research into the governance of social science. This paper has used the simple example of British government regulation of everyday epistemology to show that regulating social science as science produces undesirable consequences. The regulation of everyday epistemology occurs within government policy documents and is then transmitted to research governance structures. The examples of creating a 'slave social science' and perpetuating the 'science wars' are practical manifestations of the institutional governance of social science, and demonstrate that regulating social science as science does not work. This paper suggests that science and technology policy can redefine social science as empirical social science plus 'added interpretative value' and thereby emancipate social science as social science to realize its full utility within the national research effort.

There is undoubtedly a strong case for establishing the governance of social science as a field of study, and it can be extended to numerous areas. There is much scope for comparative research on the regulation of everyday epistemology and the various issues discussed here: the British case reveals apparent universal statements about the consequences of regulating social 
science as science, and future research could test whether, for example, the slave social science thesis holds under comparative empirical analysis.

There is also wider potential for future research beyond the scope of this paper. There is a conflict between what social science is and how it has been politically defined; the effects of this mismatch could be studied through observing adverse displacement behaviours and adaptive strategies visible throughout the bureaucratic strata of publicly funded social science research. This holds from research council policy networks, to all levels of research council business (senior research management, Council, committees, the role of the research officer, research funding applications), to academic responses and actual research directions. It is also important to consider the relationship between research initiatives and responsive research, and whether responsive research is indirectly regulated or if research initiatives are responsive in nature. A further area of interest is the fact that an Arts and Humanities Research Council (AHRC) entered the UK research council system in April 2005, prompting us to ask how it will adapt to being regulated as science, if this is indeed the way it is treated, and to note how the ESRC strategically positions itself in relation to it and if this is to the benefit or detriment of non-'positivist' approaches.

Perhaps the ultimate reflexivity of regulating everyday epistemology would be to adapt this approach to examine the place of non-social science disciplines within science governance - not only in the arts and humanities, but in the sciences also. This paper has assumed that social science is a special case. However, we can ask whether science governance fits with everyday scientific practice. Can medical research, for example, or even science and technology research, also be understood to be in the service of science and technology?

\section{ACKNOWLEDGEMENT}

The ideas in this paper were developed during my time as a visiting scholar in the Department of Government, London School of Economics and Political Science, financed by the ESRC's Science in Society Programme (the irony of the ESRC being my sponsor is not lost on me). Thanks are due to the Department for many helpful comments upon my work in progress. I would also like to thank Martin Rein, Rod Rhodes and Mark Wilson for their advice, and Mark Bevir, Des King, Phil Larkin, Ted Tapper and the anonymous referees for their valuable comments. An earlier version of this paper was presented at the 2004 Australasian Political Studies Association Conference, Adelaide.

\section{REFERENCES}


Caswill, C. 2001. 'Science Resource Decisions - Principals, Agents and Games: Thinking About Science Funding Policies, Decisions and Processes', Science Policy, Setting the Agenda for Research: Proceedings from MUSCIPOLI Workshop One, Danish Institute for Studies in Research and Research Policy.

Caswill, C. 2004. 'Turbulent Delegation: The Governance of European Research Councils and Research Policy', European Cross-National Research and Policy Seminar 5: The Impact of Social Science Research on Social Policy: Governance and Management, September 2004, London.

Clapham, J. 1946. Report of the Committee on the Provision of Social and Economic Research. Cmnd. 6868. London: HMSO.

Donovan, C. 2002. Government Policy and the Direction of Social Science Research. DPhil thesis, University of Sussex, UK.

Donovan, C. 2003. "Social Science in the Service of Science and Technology": A Case of Mistaken Identity within National Research Policy', The Australian Sociological Association 2003 Conference Proceedings.

Economic and Social Research Council (ESRC). 2004. ESRC Annual Report and Accounts 2003-04. London: The Stationery Office.

Féron, E. and J. Crowley. 2003. 'From Research Policy to the Governance of Research? A Theoretical Framework and Some Empirical Conclusions', Innovation, 16, 4, 369-93.

Finlayson, A., M. Bevir, R. A. W. Rhodes, et al. 2004. 'The Interpretive Approach in Political Science: A Symposium', British Journal of Politics and International Relations, 6, 129-64.

Fitzgerald, M.H. and E. Yule. 2003. 'The Research Ethical Review Black Box', Anthropology News, 44, 8, 64.

Flyvbjerg, B. 2001. Making Social Science Matter: Why Social Inquiry Fails and How it Can Succeed Again. New York: Cambridge University Press.

Fuller, S. 2000. The Governance of Science: Ideology and the Future of the Open Society. Buckingham: Open University Press.

Funtowicz, S., I. Shepherd, D. Wilkinson and J. Ravetz. 2000. 'Science and Governance in the European Union: A Contribution to the Debate', Science and Public Policy, 27, 5, 327-36.

Furedi, F. 2002. 'Don't Rock the Research Boat', Times Higher Education Supplement, 11 January 2002, 20.

Goldthorpe, J., R.A. Scott and M. Steuer. 2004. 'Book Review Symposium: The Scientific Study of Society', The British Journal of Sociology, 55, 1, 123-35.

Guena, A., A.J. Salter, W.E. Steinmueller (eds). 2003. Science and Innovation: Rethinking the Rationales for Funding and Governance. Cheltenham: Edward Elgar.

Hackmann, H. 2001. 'Governance Theories and the Practice of Science Policymaking', Science Policy, Setting the Agenda for Research: Proceedings from MUSCIPOLI Workshop One, Danish Institute for Studies in Research and Research Policy.

Heyworth. 1965. Report of the Committee on Social Studies. Cmnd. 2660. London: HMSO.

King, D. 1997. 'Creating a Funding Regime for Social Science Research in Britain: The Heyworth Committee on Social Studies and the Founding of the Social Science Research Council', Minerva, 53, 1-26.

King, D. 1998. 'The Politics of Social Research: Institutionalizing Public Finding Regimes in the United States and Britain', British Journal of Political Science, 28, 415-44.

Kjaer, A.M. 2004. Governance. Malden, MA: Polity/Blackwell.

Moran, M. 2003. The British Regulatory State: High Modernism and Hyper-Innovation. Oxford: Oxford University Press.

MUSCIPOLI (Managing with Uncertainty in Science Policy). 2003. 'Guidelines for the Managing with Uncertainty in the Funding of Research' (http://www.afsk.au.dk/muscipoli/index.html).

MUSCIPOLI (Managing with Uncertainty in Science Policy). n.d. 'The MUSCIPOLI Project' (http:// www.afsk.au.dk/ftp/Muscipoli/Muscipoli_objectives.pdf).

OECD (Organisation for Economic Co-operation and Development). 2003a. 'Governance of Public Research: Towards Better Practices', OECD Science E Information Technology, 9, 1-160.

OECD (Organisation for Economic Co-operation and Development). 2003b. 'Steering and Funding of Research Institutions - Country Report: UK', Governance of Public Research: Country Case Studies (http:// www.oecd.org/dataoecd/24/35/2507946.pdf).

Office of Science and Technology. 1993. Realising Our Potential: A Strategy for Science, Engineering and Technology. Cmnd. 2250. London: HMSO.

Research Councils UK (RCUK). 2004. 'Activities' (http://www.rcuk.ac.uk/activities/). 
Rhodes, R. A. W. 2003. 'What is New About Governance and Why Does it Matter?', in J.E.S. Hayward and A. Menon (eds), Governing Europe. Oxford: Oxford University Press.

Rothschild, V. 1982. An Enquiry into the Social Science Research Council. Cmnd. 8554. London: HMSO.

Van der Meulen, B. 1998. 'Science Policies as Principal-Agent Games: Institutionalization and Path Dependency in the Relation Between Government and Science', Research Policy, 27, 4, 397-414.

Williamson, E., J. Kent, T. Goodenough and R. Ashcroft. 2002. 'Social Science Gets the Ethics Treatment', Sociological Research Online 7, 4 (http://www.socresonline.org.uk/7/4/Williamson.html). 